Jurnal Ilmu Dan Teknologi Kesehatan

Vol 6, No 2, Maret 2019,

ISSN: 2338-9095 (Print)

ISSN: 2338-9109 (online)

\title{
Profil Mortalitas Stroke Associated Pneumonia Tahun 2016-2017
}

\author{
Anna Mardiana Ritonga ${ }^{1}$, Syahrizal Syarif ${ }^{1}$, Lyna Soertidewi ${ }^{2}$ \\ ${ }^{1}$ Universitas Indonesia, ${ }^{2}$ Rumah Sakit Pusat Otak Nasional Jakarta \\ Email:dr.anna.mardiana@gmail.com
}

\author{
Artikel history \\ Dikirim, Des $19^{\text {th }}, 2018$ \\ Ditinjau, Jan $22^{\text {th }}, 2019$ \\ Diterima, Jan $30^{\text {th }}, 2019$
}

\begin{abstract}
Stroke associated pneumonia (SAP) is the most common complication after stroke and has a high mortality rate. SAP mortality profile among Neuro ICU patients has not been fully investigated. Knowledge of mortality profiles can help clinical decision making for patient management. The purpose of this study was to determine the mortality profile of SAP who were treated in the Neuro ICU National Brain Centre (NBC) Hospital. This was a retrospective cohort study of the patients were hospitalized in the Neuro ICU NBC Hospital, who were diagnosed with SAP during 2016-2017. Clinical and laboratory data and the patient's status during treatment are obtained from medical record data. A total of 197 stroke patients who were treated at the Neuro ICU NBC Hospital during 2016-2017, there were 130 (65.98\%) patients diagnosed with SAP, with mortality during treatment of $77.7 \%$. The highest SAP mortality was found in male patients (75\%), in the age group $\geq 60$ years (55.4\%), GCS at admission $\leq 8$ (88.3\%), accompanied by hypertension (66.7\%) and leukocytosis (74.8\%). In bivariate analysis, the variables that were statistically significant ( $p$ $<0.05)$ were hypertension, GCS, LoS, APACHE II score, and PMR.
\end{abstract}

Keywords: stroke associated pneumonia; mortality profile

\begin{abstract}
ABSTRAK
Stroke Associated Pneumonia (SAP) adalah komplikasi stroke yang paling sering terjadi dan memiliki angka mortalitas yang tinggi. Profil mortalitas SAP di antara pasien Neuro ICU belum sepenuhnya diselidiki. Pengetahuan tentang profil mortalitas dapat membantu pengambilan keputusan klinis untuk tata laksana pasien. Penelitian ini bertujuan untuk mengetahui profil mortalitas SAP yang dirawat di Neuro ICU RSPON. Desain penelitian ini adalah penelitian kohort retrospektif, pada pasien di Neuro ICU RSPON yang didiagnosis SAP selama tahun 2016-2017. Data klinis dan laboratorium beserta status luaran pasien selama perawatan diperoleh dari data rekam medis. Dari 197 orang pasien stroke yang dirawat di Neuro ICU RSPON selama tahun 2016-2017, terdapat 130 orang (65,98\%) pasien yang terdiagnosa SAP, dengan mortalitas selama perawatan sebesar 77,7 \%. Mortalitas SAP tertinggi didapatkan pada pasien laki-laki (75\%), pada kelompok usia $\geq 60$ tahun $(55,4 \%)$, GCS saat masuk rumah sakit $\leq 8(88,3 \%)$, disertai hipertensi $(66,7 \%)$ dan leukositosis
\end{abstract}


$(74,8 \%)$. Pada analisis bivariat, didapatkan variabel yang bermakna secara statistik (nilai $\mathrm{p}<0,05)$ adalah hipertensi, GCS, lama rawat di rumah sakit, skor APACHE II, dan PMR.

Kata kunci : stroke associated pneumonia; profil mortalitas

\section{PENDAHULUAN}

Stroke Associated Pneumonia (SAP) adalah pneumonia yang terjadi pada 7 hari pertama setelah onset stroke (Smith dkk., 2015). SAP merupakan komplikasi stroke yang paling sering terjadi dengan perkiraan insidensi $5,6 \%-32 \%$ dari kasus stroke akut (Katzan dkk., 2007). SAP memiliki risiko relatif 3,0 untuk mortalitas, meningkatkan kemungkinan mortalitas 14 kali dan morbiditas 7 kali (de Castillo, Sumalapao dan Pascual, 2017). Mortalitas SAP tinggi dalam 30 hari (OR 2,2 [95\% CI 1,8-2,7]) dan mortalitas SAP meningkat dalam 1 tahun (OR 3,0 [95\% CI 2,5-3,7]) (Finlayson, 2011).

SAP menyebabkan lama rawat di rumah sakit memanjang, sehingga meningkatkan biaya rawat pasien stroke (Katzan dkk., 2007). Rata-rata biaya yang disesuaikan untuk hospitalisasi untuk pasien SAP di Amerika Serikat adalah \$21.043 (95\% CI $\$ 19.698-22.387)$ dan $\$ 6.206 \quad(95 \% \quad$ CI $\$ 6,150-6,262)$ untuk pasien stroke tanpa pneumonia (Katzan dkk., 2007).

Insiden dan mortalitas SAP tertinggi diamati terjadi di unit perawatan intensif dimana $10 \%$ - $25 \%$ pasien stroke yang dirawat menderita SAP (Finlayson, 2011). Insiden yang lebih tinggi di unit perawatan intensif dibandingkan dengan ruang rawat stroke lainnya dijelaskan oleh adanya ventilasi mekanik dan keparahan stroke yang lebih tinggi menyebabkan tingkat yang lebih tinggi dari aspirasi di antara pasien di unit perawatan intensif (Hannawi, 2013). Profil mortalitas SAP di antara pasien di unit perawatan intensif belum sepenuhnya diselidiki. Akses yang lebih cepat untuk perawatan rawat inap yang terorganisir menghasilkan pengurangan mortalitas 30 hari (OR 0,50 [95\% CI 0,41-0,61]) (Finlayson, 2011).

Pengetahuan tentang profil mortalitas dapat membantu pengambilan keputusan klinis untuk tatalaksana pasien sehingga dapat meningkatkan mutu pelayanan. Pada saat ini belum pernah dilakukan penelitian mengenai profil mortalitas SAP yang dirawat di Neurological Intensive Care Unit (Neuro ICU) Rumah Sakit Pusat Otak Nasional (RSPON). Tujuan penelitian ini untuk mengetahui profil mortalitas SAP yang dirawat di Neuro ICU RSPON di Jakarta, Indonesia. 


\section{METODE}

Desain penelitian ini adalah penelitian kohort retrospektif. Penelitian ini mengambil data rekam medis pasien SAP yang dirawat di Neuro ICU RSPON selama tahun 2016-2017. Populasi pada penelitian ini adalah pasien SAP. Sampel pada penelitian ini adalah semua pasien SAP yang dirawat di Neuro ICU RSPON selama tahun 2016-2017 yang memenuhi kriteria penerimaan penelitian. Pengambilan sampel untuk penelitian ini adalah berdasarkan metode purposive sampling. Berdasarkan perhitungan rumus, besar sampel minimal yang dibutuhkan adalah sebanyak 126 orang.

Pengumpulan data dilakukan dengan penelusuran data rekam medis. Pasien SAP yang dipilih berdasarkan kriteria inklusi dan kriteria eksklusi. Kriteria inklusi pada penelitian ini adalah pasien terdiagnosa SAP, usia lebih dari 18 tahun, dirawat di Neuro ICU RSPON dan data pasien diizinkan untuk diteliti. Kriteria eksklusi pada penelitian ini adalah pediatrik, penyakit dengan manifestasi klinis yang serupa dengan pneumonia seperti tuberkulosis, tumor paru, edema pulmonal, emboli paru, atelektasis pulmonal, dan data rekam medik tidak lengkap atau hilang.
Variabel yang diteliti yaitu jenis kelamin (laki-laki, perempuan), usia (<60 tahun, $\geq 60$ tahun), Glasgow Coma Scale (GCS), hipertensi, leukositosis, gagal ginjal akut, diagnosis primer masuk (berdasarkan jenis stroke), lama rawat di Neuro ICU, lama rawat di rumah sakit, skor APACHE (Acute Physiology and Chronic Evaluation) II, dan Predicted Mortality Rate (PMR) berdasarkan skor APACHE II.

Glasgow Coma Scale (GCS) adalah skala yang dipakai untuk menilai tingkat kesadaran pasien, terdiri dari tiga penilaian terhadap respon yang ditunjukkan oleh pasien setelah diberi stimulus tertentu, yaitu respon buka mata, respon motorik terbaik, dan respon verbal. Setiap penilaian mencakup poin. Nilai GCS yang tertinggi adalah 15 dan terendah adalah 3.

Hipertensi yang dimaksud dalam penelitian ini adalah sesuai dengan definisi Joint National Committee (JNC) 8 yaitu tekanan darah sistolik lebih dari 140 $\mathrm{mmHg}$ serta diastolik lebih dari $90 \mathrm{mmHg}$ (James et al., 2013).

Nilai referensi laboratorium RSPON untuk leukositosis adalah apabila sel darah putih jumlahnya meningkat lebih dari 10.000 leukosit per mm kubik darah manusia 
dewasa. Gagal ginjal akut adalah suatu sindrom akibat kerusakan metabolik atau patologik pada ginjal yang ditandai dengan penurunan fungsi ginjal, serum kreatinin naik sebesar $\geq 0,3 \mathrm{mg} / \mathrm{dl}$ dalam waktu 48 jam atau meningkat $\geq 1,5$ kali lipat dari nilai referensi.

Skor APACHE adalah suatu metode analisis keadaan pasien di ruang intensif, digunakan untuk mengukur tingkat keparahan penyakit dan memprediksi mortalitas. Skor APACHE pertama kali diperkenalkan oleh William Knaus di Universitas George Washington pada tahun 1981. Tahun 1985 sistem skor APACHE orisinil mengalami reduksi dari 34 variabel menjadi 12 variabel sehingga APACHE II ini dikenal sebagai simplified APACHE. Sistem skor APACHE II lebih diterima karena data yang dibutuhkan untuk menentukan skor lebih sederhana, definisi tiap variabel jelas dan reproduksibel serta dikumpulkan dari pemeriksaan rutin pasien di ICU. APACHE II mengklasifikasikan derajat parahnya suatu penyakit berdasarkan 12 parameter yaitu suhu rektal, mean arterial pressure, frekuensi nadi, frekuensi napas, $\mathrm{PO}$, $\mathrm{pH}$ arteri, natrium serum, kalium serum, kreatinin serum, hematokrit dan hitung jenis lekosit. Data perhitungan skor APACHE II bervariasi dari 0 sampai 71. Parameter diukur setelah 24 jam pertama pasien masuk ICU. Semakin tinggi skor makin parah kondisi pasien dan semakin besar risiko kematiannya.

Beberapa studi mengkorelasikan antara skor APACHE II dengan lama tinggal pasien di ICU (LoS/length of stay). Skor APACHE bisa dipergunakan juga sebagai Predicted Mortality Rate : nilai 0-4 : $1 \%$, nilai $5-9: 3 \%$, nilai $10-14: 7 \%$, nilai 15 19 : $12 \%$, nilai $20-24: 30 \%$, nilai $25-29$ : $35 \%$, nilai $30-34: 73 \%$, nilai $35-71: 88$ $\%$. Ini artinya semakin tinggi skornya semakin lama pasien dirawat di ruang ICU, semakin besar probabilitas kematian dan semakin besar dana yang dibutuhkan.

Setelah didapatkan sampel penelitian, dilakukan pemeriksaan dan pengolahan data. Dilakukan analisis univariat dan analisis bivariat variabel yang diteliti terhadap mortalitas.

\section{HASIL DAN PEMBAHASAN}

Data dari buku registrasi pasien tercatat sebanyak 197 orang pasien stroke yang dirawat di Neuro ICU RSPON selama tahun 2016-2017. Hasil penelusuran menunjukkan jumlah pasien SAP sebanyak 130 orang $(65,98 \%)$, mortalitas sebesar 77,7\%. Pasien SAP sebagian besar berjenis kelamin laki-laki $(64,6 \%)$, usia $\geq 60$ tahun $(52,3 \%)$, dengan diagnosis primer stroke hemoragik $(67,7 \%)$, dengan 
hipertensi $(57,7 \%)$, leukositosis $(82,3 \%)$, GCS saat masuk rumah sakit $\leq 8(72,3 \%)$, rerata skor APACHE II sebesar 24 (1830). Lama rawat di ICU sebesar $57,6 \%$ dari keseluruhan lama rawat di rumah sakit. Karakteristik pasien SAP secara lengkap bisa dilihat pada tabel 1 .

Tabel 1. Karakteristik pasien SAP

\begin{tabular}{ll}
\hline Variabel & $\mathbf{N}=\mathbf{1 3 0}$ \\
\hline Jenis kelamin, n (\%) & \\
$\quad$ - Laki-laki & $84(64,6)$ \\
$\quad$ - Perempuan & $46(35,4)$ \\
Usia (tahun), n (\%) & \\
$\quad$ - <60 tahun & $62(47,7)$ \\
$\quad$ - $\geq 60$ tahun & $68(52,3)$ \\
Diagnosis primer, n (\%) & \\
$\quad$ - Stroke Hemoragik & $99(67,7)$ \\
$\quad$ - Stroke Iskemik & $42(32,3)$ \\
Hipertensi, n (\%) & \\
$\quad$ - Ya & $75(57,7)$ \\
- Tidak & $55(42,3)$ \\
Gagal Ginjal Akut, n (\%) & \\
$\quad$ - Ya & $26(20)$ \\
$\quad$ - Tidak & $104(80)$ \\
GCS, n (\%) & \\
$\quad$ - $\quad 8$ & $94(72,3)$ \\
- 9-15 & $36(27,7)$ \\
Leukositosis, n (\%) & \\
$\quad$ - Ya & $107(82,3)$ \\
$\quad$ - Tidak & $23(17,7)$ \\
Outcome & \\
$\quad$ - Hidup, n (\%) & \\
- Meninggal, n (\%) & $29(22,3)$ \\
Skor APACHE II, median (RIK) & $101(77,7)$ \\
LOS Neuro ICU, median (RIK) & $24.08 \pm 5,7$ \\
LOS RS, median (RIK) & $9,03 \pm 9,8$ \\
Ketangan : Signikan secara statistik & $15,68 \pm 15,7$ \\
\hline
\end{tabular}

Keterangan : $*$ Signifikan secara statistik

Singkatan : RIK = Rentang Inter Kuartil, PMR = Predicted Mortality Rate, GCS = Glasgow Coma Scale, APACHE = Acute Physiology and Chronic Evaluation, LOS $=$ Length of Stay, Neuro ICU $=$ Neurological Intensive Care Unit

Hubungan analisis bivariat dari variabel bebas diperlihatkan pada tabel 2. Angka mortalitas pasien SAP didapatkan tertinggi pada pasien laki-laki, usia $\geq 60$ tahun, dengan diagnosa primer stroke hemoragik, leukositosis, GCS saat masuk rumah sakit $\leq 8$, dan rerata skor APACHE II sebesar $24,96 \pm 5,2$. Pada analisis bivariat, variabel yang bermakna secara statistik (nilai $\mathrm{p}<0,05)$ adalah hipertensi, GCS, lama 
rawat di rumah sakit, skor APACHE II, dan PMR.

Tabel 2. Hasil analisis bivariat dari variabel bebas

\begin{tabular}{|c|c|c|c|c|}
\hline & Meninggal & Hidup & RR $(95 \%$ CI $)$ & Nilai p \\
\hline \multicolumn{5}{|l|}{ Jenis kelamin, $n=130$} \\
\hline - Laki-laki & 63 & 21 & $1,101(0,919-$ & 0,438 \\
\hline - Perempuan & 38 & 8 & $1,320)$ & \\
\hline \multicolumn{5}{|l|}{ Usia (tahun), $n=130$} \\
\hline$-\quad \geq 60$ tahun & 56 & 12 & $1,135(0,940-1,370)$ & 0,260 \\
\hline$-<60$ tahun & 45 & 17 & & \\
\hline \multicolumn{5}{|l|}{ Hipertensi, n=130 } \\
\hline - Tidak & 51 & 4 & $1,391(1,166-$ & $0,001 *$ \\
\hline - $\quad \mathrm{Ya}$ & 50 & 25 & $1,659)$ & \\
\hline \multicolumn{5}{|l|}{ Gagal Ginjal Akut, $n=130$} \\
\hline - Tidak & 83 & 21 & $1,153(0,877-$ & 0,371 \\
\hline - Ya & 18 & 8 & $1,516)$ & \\
\hline \multicolumn{5}{|l|}{ Diagnosa, $n=130$} \\
\hline - Stroke Hemoragik & 66 & 22 & $1,111(0,927-$ & 0,400 \\
\hline - Stroke Iskemik & 35 & 7 & $1,332)$ & \\
\hline \multicolumn{5}{|l|}{ Leukositosis, $\mathrm{n}=130$} \\
\hline - Ya & 80 & 27 & $1,221(1,033-$ & 0,146 \\
\hline - Tidak & 21 & 2 & $1,444)$ & \\
\hline \multicolumn{5}{|l|}{ GCS, $n=130$} \\
\hline$-\quad \leq 8$ & 83 & 11 & $1,766(1,263-$ & $0,000 *$ \\
\hline$-9-15$ & 18 & 18 & $2,468)$ & \\
\hline LOS Neuro ICU, median (RIK) & $8,55 \pm 8,3$ & $10,69 \pm 13,7$ & & 0,471 \\
\hline LOS RS, median (RIK) & $13,70 \pm 14,1$ & $22,59 \pm 19,2$ & & $0,001 *$ \\
\hline Skor APACHE II, median(RIK) & $24,96 \pm 5,2$ & $21,00 \pm 6,2$ & & $0,004^{*}$ \\
\hline PMR, median (RIK) & $49,84 \pm 17,2$ & $38,31 \pm 6,1$ & & $0,003 *$ \\
\hline
\end{tabular}

Keterangan : $*=$ Signifikan secara statistik

Singkatan $:$ RIK $=$ Rentang Inter Kuartil, PMR $=$ Predicted Mortality Rate, GCS $=$ Glasgow Coma Scale, $\mathrm{APACHE}=$ Acute Physiology and Chronic Evaluation, $\mathrm{LOS}=$ Length of Stay, Neuro ICU = Neurological Intensive Care Unit

Penelitian ini dilakukan untuk Associated Pneumonia oleh (Wandira RD, mendapatkan profil mortalitas SAP di Amalia L., 2018) di Ruang Rawat RSPON tahun 2016-2017. Dalam Neurologi RSUP Dr. Hasan Sadikin, penelitian ini sebagian besar pasien SAP Bandung, yang menemukan bahwa pasien berjenis kelamin laki-laki (64,6\%), usia $\geq$ SAP terbanyak pada pasien laki-laki 60 tahun, GCS $\leq 8$ saat masuk rumah sakit $(81,5 \%)$. Hasil ini hampir sama dengan penelitian hubungan antara derajat keparahan stroke dengan kejadian Stroke $(58,3 \%)$, kelompok usia 65-74 tahun $(41,7 \%)$, serta pada subjek dengan penurunan kesadaran (Wandira, Amalia dan Fuadi, 2018). 
Dari penelitian ini terlihat bahwa mortalitas pasien SAP lebih banyak terjadi pada pasien laki-laki daripada perempuan. Riwayat kebiasaan merokok lebih banyak didapatkan pada pasien laki-laki dibandingkan pasien perempuan. Penelitian yang dilakukan oleh (Ovbiagele B, Weir CJ, Saver JL, 2006), mengatakan bahwa merokok memiliki pengaruh terhadap keluaran klinis dari pasien stroke terutama 3 bulan setelah onset stroke akut. Adanya riwayat kebiasaan merokok pada pasien akan memberikan keluaran klinis yang lebih buruk dibandingkan pada kelompok pasien yang tidak merokok (Nazarian et al, 2009).

Mortalitas pasien SAP pada penelitian ini cenderung terjadi pada kelompok usia $\geq 60$ tahun. Hal ini sejalan dengan penelitian oleh (Nazarian DJ, Eddy OL, Lukens TW, Weingart SD, 2009) di Amerika Serikat mendapatkan rerata usia pasien pneumonia adalah 77 tahun, sedangkan penelitian (Zalacain R, Torres A, Celis R, Blanquer J, Aspa J, Esteban L, 2013) di Spanyol mendapatkan rerata usia pasien pneumonia adalah 76,3 tahun (Zalacain et al., 2003).

Pasien SAP pada penelitian ini cenderung mengalami leukositosis, tetapi bila dihubungkan dengan diagnosis pneumonia, jumlah leukosit $>10.000 / \mathrm{mm} 3$ tidak memiliki kemaknaan secara statistik $(\mathrm{p}=0,8$, OR 1,09; IK 95\% 0,52- 2,27). Pada penelitian ini dihitung skor APACHE II untuk memprediksi mortalitas pasien stroke dengan pneumonia, didapatkan rerata skor APACHE II pada pasien yang meninggal sebesar 24,96 $\pm 5,2$ dengan nilai $\mathrm{p}=0,004$, menunjukkan derajat berat penyakit pasien SAP yang dirawat di Neuro ICU RSPON. Skor APACHE II yang didapatkan pada penelitian ini mirip dibandingkan dengan penelitian sistem skor APACHE II sebagai prediksi mortalitas pasien rawat instalasi perawatan intensif, oleh Diah dkk. di ICU RS Persahabatan yang mendapatkan rerata skor APACHE II pada pasien yang meninggal sebesar $25 \pm 1,3$ (D. Handayani, N. Arief, B. Swidarmoko, P. Astowo, 2006)

Dari skor APACHE II dapat dihitung PMR (Predicted Mortality Rate) sehingga tindakan yang lebih tepat dapat segera diambil dari saat pertama pasien masuk rumah sakit. Tingkat mortalitas pasien SAP yang tinggi dengan PMR hampir 50 $\%$ dapat juga dipengaruhi oleh pemberian terapi yang diberikan selama perawatan di Neuro ICU maupun perawatan di ruang perawatan sebelumnya. Perawatan Neuro ICU yang mahal juga menimbulkan 
pertimbangan dokter maupun keluarga untuk merujuk pasien ke Neuro ICU terlambat sehingga datang dalam kondisi yang buruk. Pasien dirujuk ke Neuro ICU jika telah terjadi gagal napas yang membutuhkan ventilasi mekanis sehingga prognosisnya buruk. Pada penelitian ini tidak dilakukan analisis terhadap perawatan dan terapi baik di Neuro ICU maupun ruang perawatan sebelumnya. Hal ini perlu diperhatikan untuk meningkatkan kualitas terapi dan perawatan pasien SAP di Neuro ICU dan evaluasi terhadap penentuan indikasi pasien SAP yang akan dirawat di Neuro ICU sehingga memberikan outcome yang lebih baik.

Lama rawat pasien SAP yang memanjang akan menyebabkan dampak mortalitas dan juga finansial. Pada penelitian ini didapatkan rerata lama rawat inap di rumah sakit dan di Neuro ICU untuk pasien SAP yang meninggal, berturut-turut sebesar $13,70 \pm 14,1$ hari dan $8,55 \pm 8,3$. Dapat dihitung bahwa pasien SAP yang meninggal dalam perawatan, rata-rata dirawat di Neuro ICU selama 62,4\% dari keseluruhan lama rawat di rumah sakit. Selain mahalnya biaya perawatan, lama rawat pasien SAP yang memanjang juga akan menyebabkan kapasitas tempat tidur di Neuro ICU menjadi semakin terbatas sehingga mempengaruhi alur pasien Neuro ICU berikutnya. Pengaturan pasien berdasarkan lama rawat diperlukan agar alur pasien lancar dengan tetap memperhatikan faktor hukum dan etika medis.

\section{SIMPULAN}

Profil mortalitas SAP di Neuro ICU RSPON tahun 2016-2017 hampir sama dengan penelitian lain yang dilaksanakan di negara berkembang maupun negara maju.

\section{UCAPAN TERIMA KASIH}

Ucapan terima kasih untuk Direktur Utama Rumah Sakit Pusat Otak Nasional yang sudah mengizinkan penulis untuk mengambil data penelitian di Rumah Sakit Pusat Otak Nasional.

\section{DAFTAR PUSTAKA}

de Castillo, L. L. C., Sumalapao, D. E. P. and Pascual, J. L. R. 2017. 'Risk factors for pneumonia in acute stroke patients admitted to the emergency department of a tertiary government hospital', National Journal of Physiology, Pharmacy and Pharmacology, 7(8), pp. 855-859. doi:10.5455/njppp.2017.7.04110080 52017.

D. Handayani, N. Arief, B. Swidarmoko, P. Astowo, and M. S. D. 2006. 'Sistem skor acute physiology and chronic health evaluation (APACHE) II sebagai prediksi mortalitas pasien rawat instalasi 
perawatan intensif', J Pulmo, 34(1), pp. 36-45.

Finlayson, O. 2011. 'Risk factors, inpatient care, and outcomes of pneumonia after ischemic stroke'.

Hannawi, Y. et al. 2013. 'Strokeassociated pneumonia: Major advances and obstacles', Cerebrovascular Diseases', 35(5), pp. 430-443.

James PA, Oparil S, Carter BL, Cushman WC, Dennison C, Handler J, dkk. 2013. Evidence-based guideline for the management of high blood pressure in adults: Report from the panel member appointed to the eight joint national committee (JNC 8). JAMA; 18 Dec 2013

Katzan, I. L. et al. 2007. 'The cost of pneumonia after acute stroke', Neurology, 68(22), pp. 1938-1943. doi:

10.1212/01.wnl.0000263187.08969. 45.

Nazarian DJ, Eddy OL, Lukens TW, Weingart SD, Decker WW. 2009. Clinical policy: Critical issue in the managenment of adult patients presenting to the emergency departement with community- acquired pneumonia. Ann Emerg Med;54(5):704-29

Ovbiagele B, Weir CJ, Saver JL, Muir KW. 2006. Effect of smoking status on outcome after acute ischemic stroke. Cerebrovasc Dis.;21:260-5

Smith, C. J. et al. 2015. 'Diagnosis of Stroke-Associated Pneumonia: Recommendations From the Pneumonia in Stroke Consensus Group', Stroke; a journal of cerebral circulation, 46(8), pp. 2335-2340. doi:

10.1161/STROKEAHA.115.009617.

Wandira RD, Amalia L., Fuadi I. 2018. Hubungan antara derajat keparahan stroke dengan kejadian strokeassociated pneumonia. Neurona ; $35(2)$

Zalacain R, Torres A, Celis R, Blanquer J, Aspa J, Esteban L, et al. 2003. Community-acquired pneumonia in the elderly: Spanish multicentre study. Eur Respir J.;21(2):294-302. 